\title{
Effect of Different Weight Classes of Processed Clarias gariepinus on Yields of Fish Fillet and Fishmeal Production
}

\author{
Salisu A. A. A. ${ }^{1}$, Faturoti E. O. ${ }^{2}$ \\ ${ }^{1}$ Fisheries Component, Ogun State Agricultural Development Programme, Abeokuta, Nigeria \\ ${ }^{2}$ Department of Aquaculture and Fisheries Management, University of Ibadan, Ibadan, Nigeria
}

\begin{abstract}
Four weight classes of African Catfish, Clarias gariepinus (Burchell 1822), - below $500 \mathrm{~g}, 500 \mathrm{~g}-999 \mathrm{~g}, 1.000 \mathrm{~kg}-1.499$ $\mathrm{kg}$ and $1.500 \mathrm{~kg}-1.999 \mathrm{~kg}$ - were processed into fish fillets and the by-product into fishmeal. The fillet yields ranged between $31.85 \%$ - 39.50\% with the biggest fish group producing the highest fillet yield but lowest amount of solid waste (58.25\%). There was a direct relationship between fish weight and fillet yield as well as solid "waste" yield. The fishmeal produced from the solid "waste" also revealed a direct relationship between the fish weight and the amount of fishmeal produced. The biggest fish group (1.500 $\mathrm{kg}-1.999$ $\mathrm{kg}$ ), despite having the lowest amount of raw material, produced the highest amount of fishmeal with the best conversion ratio 4.48:1 (raw fish: dried fishmeal). Proximate analysis revealed crude protein range of $55.87 \pm 0.16$ to $57.40 \pm 0.95$ with the biggest fish group having the highest crude protein. There were significant differences among the fish fillet, solid waste and drip loss yields of the fish weight classes. Likewise, there was a significant difference between the crude protein and ash contents of the smallest fish group and those of the biggest fish group.
\end{abstract}

Keywords: Different weight classes. Clarias gariepinus. Fillet yields. Waste yields. Fishmeal

\section{Introduction}

Clarias gariepinus (Burchell, 1822), (African catfish), is the most widely cultured fish species in Nigeria (Fagbenro and Arowosegbe, 1991) and indeed Africa (Garibaldi, 1996; cited by Fagbenro et al, 2013) probably because it is tasty, hardy, tolerates poor water quality conditions (Idodo-Umeh, 2003) and readily accept different kinds of feed ingredients included in its diet (Faturoti, 2000). It also has high consumer preference ranking, fast growth rate to marketable size within a short time, early maturity and ability to breed easily in captivity. Clarias gariepinus table size is usually consumed by man whole as fresh fish. However value could be added to the fish by processing it into fish fillets, this provides more choices to the consumers, gives more profit to the farmer and reduces possibility of fish glut.

Fish fillets (fish flesh excluding bones, viscera and the head), which may be skinless or with the skin on, are getting popular in Nigeria (Adeyemi et al, 2012) probably because they are convenient for housewife to cook and easier to eat. The by-products of fish fillet production, that is, the head, viscera, the backbone and the trimmings, could serve as raw material for the production of fishmeal.

Fishmeal constitutes a substantial part of formulated feed for diverse fish species and livestock globally (FAO, 1998) and this universal use is as a result of its excellent amino acid profile, palatability and high nutritive value (Alceste and Jory, 2000). Fishmeal is the most expensive ingredient in aquaculture diets probably because of high demand and dwindling landing of captured fish hence production of fishmeal from locally available raw material is germane to aquaculture development.

Adeyemo (2013), Adeyemi et al (2012) and Eyo (2001) reported fillet yields of Clarias gariepinus among other fish species. However, works on fillet yields of Clarias gariepinus of different weight classes are scarce. Also, there is little or no information on yields and chemical composition of fishmeal produced from the waste generated through processing of Clarias gariepinus of different weight classes into fish fillets.

This research work was then aimed at:

- Determining the effect of different weight classes on the yields of skinless fillets obtainable from processed Clarias gariepinus.

- Determining the effect of different fish weight classes on the yields and chemical composition of fishmeal produced from the waste generated from processing Clarias gariepinus into fillets.

- Recommending the best weight class of Clarias gariepinus that could be processed into fish fillet for the highest amount of fillet yields.

\section{Materials and Method}

The different sizes of Clarias gariepinus were obtained live from Aquabeet fish farm, Sango-ota, Ogun state, Nigeria and transported to Fish Technology Department Laboratory, Nigerian Institute for Oceanography and Marine Research (NIOMR), Lagos, Nigeria. 


\section{International Journal of Science and Research (IJSR) \\ ISSN (Online): 2319-7064 \\ Index Copernicus Value (2013): 6.14 | Impact Factor (2015): 6.391}

Fish Preparation and Processing

Four groups of Clarias gariepinus of different weight classes used in this work were:

Clarias Group A - Clarias gariepinus of below 500g each

Clarias Group B - Clarias gariepinus of between $500 \mathrm{~g}-$ 999g each

Clarias Group C - Clarias gariepinus of between $1.000 \mathrm{~kg}$ $1.499 \mathrm{~kg}$ each

Clarias Group D - Clarias gariepinus of between $1.500 \mathrm{~kg}$ $1.999 \mathrm{~kg}$ each

Prior to filleting, the weight of each fish was measured using sensitive weighing balance (OHAUS model PA 4101, capacity $4100 \mathrm{~g}$ ) to ensure it fell within the group and the total weight of $40 \mathrm{~kg}$ was obtained for each replicate of each group.

Fish Fillet Production: Each replicate was processed into fish fillets and the by-product into fishmeal in the laboratory of Department of Fish Technology, NIOMR. The fish were stunned using $5 \%(\mathrm{w} / \mathrm{w})$ table salt $(\mathrm{NaCl})$ (Adeyemi et al, 2012) and then washed manually with water containing $3.4 \%$ $(\mathrm{w} / \mathrm{v})$ common alum (hydrated potassium aluminium sulphate: $\mathrm{KAl}\left(\mathrm{SO}_{4}\right)_{2} \cdot 12 \mathrm{H}_{2} \mathrm{O}$ ). (Adeyemi et al, 2012) to remove slime for easy handling during filleting. Manual fish filleting technique as described by Rival (2011) was adopted using stainless steel filleting knives to produce skinless, single fish fillets. Weights of skinless fillets and by-products were taken and recorded.

The percentages of product and by-products were calculated as:

$\%$ Fillet yield $=\underline{\text { TWFF }} \times 100$

TWF

\%Solid "waste" yield = TWSW $\times 100$

TWF

$\%$ Drip loss yield $=\underline{\mathrm{TWF}}-(\mathrm{TWFF}+\mathrm{TWSW}) \times 100$

TWF

where:

TWFF $=$ total weight of fish fillet

TWF $=$ total weight of fish

TWSW $=$ total weight of solid waste
Production of Fishmeal: The by-product (solid "waste") obtained from the production of fillets from each of the replicate was used to produce Clarias fishmeal using NIOMR's fishmeal plant (Denmark, type FR 100) as described by Akande et al. (2014).

Conversion ratio of raw fish to fishmeal was calculated as: Weight of raw fish used $(\mathrm{kg})$

Weight of fishmeal produced $(\mathrm{kg})$

Conversion percentage was calculated as:

Weight of fishmeal produced (kg) x 100

Weight of raw fish used (kg)

Proximate Analysis: Each of the fishmeal produced was analyzed for proximate composition using the standard methods of A.O.A.C., (2000). Each analysis was carried out in triplicates.

Statistical Analysis: All data obtained in this research work were expressed in means $\pm \mathrm{SD}$ and subjected to one way analysis of variance (ANOVA) at 5\% level of significance using SPSS for windows (version 16.0). Least Significant Difference test was then used to determine the differences among the means. Yields obtained were also expressed as percentages.

\section{Results}

Clarias Group D (fish of $1.500 \mathrm{~kg}-1.999 \mathrm{~kg}$ ) yielded the highest amount of fish fillet $(15.80 \pm 0.01 \mathrm{~kg})$, the lowest amount of solid fish "waste" $(23.30 \pm 0.01 \mathrm{~kg})$ and the lowest amount of drip-loss $(0.9 \pm 0.02 \mathrm{~kg})$, while Clarias Group A (fish below 500g) yielded the lowest amount of fish fillet $(12.74 \pm 0.02 \mathrm{~kg})$ but the highest amount of solid fish "waste" $(25.40 \pm 0.03 \mathrm{~kg})$ and the highest amount of drip loss $(1.80 \pm 0.05 \mathrm{~kg})$ as shown in Table 1 . Conversion percentage of raw fish to fish fillet was highest in Clarias Group D (39.50\%) and lowest in Clarias Group A (31.85\%). Percentage of solid waste generated was highest in Clarias Group A (63.50\%) and lowest in Clarias Group D (58.25\%) while drip loss percentage was also highest in Clarias Group A (4.65\%) and lowest in Clarias Group D (2.25\%) as shown in Table 2.

Table 1: Yields of processed Clarias gariepinus of different weight classes

\begin{tabular}{|c|c|c|c|c|}
\hline Products & Clarias Group A & Clarias Group B & Clarias Group C & Clarias Group D $^{\text {B }}$ \\
\hline Total fish weight (kg) & $40.00 \pm 0.00^{\mathrm{a}}$ & $40.00 \pm 0.00^{\mathrm{a}}$ & $40.00 \pm 0.00^{\mathrm{a}}$ & $40.00 \pm 0.00^{\mathrm{a}}$ \\
Weight of fillets (kg) & $12.74 \pm 0.02^{\mathrm{a}}$ & $13.20 \pm 0.02^{\mathrm{b}}$ & $14.38 \pm 0.01^{\mathrm{c}}$ & $15.80 \pm 0.01^{\mathrm{d}}$ \\
\hline Weight of Solid Waste (kg) & $25.40 \pm 0.03^{\mathrm{a}}$ & $25.12 \pm 0.04^{\mathrm{b}}$ & $24.58 \pm 0.02^{\mathrm{c}}$ & $23.30 \pm 0.01^{\mathrm{d}}$ \\
\hline Drip Loss (kg) & $1.86 \pm 0.05^{\mathrm{a}}$ & $1.68 \pm 0.06^{\mathrm{b}}$ & $1.04 \pm 0.03^{\mathrm{c}}$ & $0.90 \pm 0.02^{\mathrm{d}}$ \\
\hline
\end{tabular}

The above values are means of triplicate data \pm SD.

Mean values in each row with different superscripts are significantly different $(P<0.05)$. 


\section{International Journal of Science and Research (IJSR) ISSN (Online): 2319-7064 \\ Index Copernicus Value (2013): 6.14 | Impact Factor (2015): 6.391}

Table 2: Yield percentages of processed Clarias gariepinus of different weight classes

\begin{tabular}{|l|l|l|l|l|}
\hline Products & Clarias Group A & Clarias Group B & Clarias Group C $^{\text {Clarias Group D }}$ \\
\hline Fish Fillets (\%) & $31.85 \pm 0.04^{\mathrm{a}}$ & $33.00 \pm 0.04^{\mathrm{b}}$ & $35.95 \pm 0.03^{\mathrm{c}}$ & $39.50 \pm 0.03^{\mathrm{d}}$ \\
\hline Solid Waste (\%) & $63.50 \pm 0.09^{\mathrm{a}}$ & $62.80 \pm 0.09^{\mathrm{b}}$ & $61.45 \pm 0.05^{\mathrm{c}}$ & $58.25 \pm 0.03^{\mathrm{d}}$ \\
\hline Drip Loss (\%) & $4.65 \pm 0.13^{\mathrm{a}}$ & $4.20 \pm 0.15^{\mathrm{b}}$ & $2.60 \pm 0.08^{\mathrm{c}}$ & $2.25 \pm 0.05^{\mathrm{d}}$ \\
\hline
\end{tabular}

The above values are means of triplicate data \pm SD.

Mean values in each row with different superscripts are significantly different $(\mathrm{P}<0.05)$.

\section{Fishmeal Yields}

Clarias Group D (fish of $1.50 \mathrm{~kg}-1.99 \mathrm{~kg}$ ), despite having the lowest amount of raw material $(23.30 \pm 0.01 \mathrm{~kg})$, yielded the highest amount of fishmeal $(5.20 \pm 0.00 \mathrm{~kg})$ with conversion ratio of raw fish to fishmeal being 4.48:1 (22.32\%) while Clarias Group A (fish below 500 g) with $25.40 \pm 0.03 \mathrm{~kg}$ of raw material yielded the lowest amount of fishmeal $(4.80 \pm 0.01 \mathrm{~kg})$ with conversion ration of raw fish to fishmeal being 5.29:1 (18.90\%) as shown in Table 3.

Table 3: Results Obtained after Production of Fishmeal from the Solid Waste

\begin{tabular}{|c|c|c|c|c|}
\hline Products & Clarias Group A & Clarias Group B & Clarias Group C & Clarias Group D \\
\hline Weight of Raw Fish (kg) & $25.40 \pm 0.03^{\mathrm{a}}$ & $25.12 \pm 0.03^{b}$ & $24.58 \pm 0.02^{\mathrm{C}}$ & $23.30 \pm 0.01^{\mathrm{d}}$ \\
\hline Weight of Fishmeal Produced (kg) & $4.80 \pm 0.01^{\mathrm{a}}$ & $4.85 \pm 0.01^{\mathrm{b}}$ & $5.00 \pm 0.01^{\mathrm{C}}$ & $5.20 \pm 0.00^{\mathrm{d}}$ \\
\hline Conversion Ratio (raw fish: fishmeal) & $5.29: 1^{\mathrm{a}}$ & $5.18: 1^{b}$ & $4.92: 1^{\mathrm{C}}$ & $4.48: 1^{\mathrm{d}}$ \\
\hline Percentage (\%) & $18.90^{\mathrm{a}}$ & $19.31^{\mathrm{b}}$ & $20.34^{\mathrm{C}}$ & $22.32^{\mathrm{d}}$ \\
\hline
\end{tabular}

The above values are means of triplicate data \pm SD .

Mean values in each row with different superscripts are significantly different $(\mathrm{P}<0.05)$.

Analysed Composition of Clarias Fishmeal: Clarias Group D fishmeal had the highest crude protein content of $57.40 \pm$ 0.95 and it is significantly higher $(\mathrm{P}<0.05)$ than Clarias Group A Fishmeal with crude protein of $55.87 \pm 0.16$. However, crude protein content of Clarias Group A fishmeal was not significantly different from that of Clarias Groups B and $\mathrm{C}$ fishmeal while crude protein contents of Clarias Groups B and C fishmeal were also not significantly different from that of Clarias Group D fishmeal. In terms of Ash content, Clarias Group A fishmeal was not significantly better from Clarias Group B fishmeal but both were significantly different from Clarias Groups C and D fishmeal which were also significantly different from each other. (Table 4).

Table 4: Analyzed Composition of Clarias Fishmeal

\begin{tabular}{|c|c|c|c|c|}
\hline Parameter & CA FM & CB FM & CC FM & CD FM \\
\hline Crude Protein & $55.87 \pm$ & $56.70 \pm$ & $56.90 \pm$ & $57.40 \pm$ \\
& $0.16^{\mathrm{a}}$ & $0.26^{\mathrm{ab}}$ & $0.26^{\mathrm{ab}}$ & $0.95^{\mathrm{b}}$ \\
\hline Ether Extract & $8.00 \pm$ & $8.05 \pm .50^{\mathrm{a}}$ & $8.15 \pm$ & $8.50 \pm$ \\
& $0.00^{\mathrm{a}}$ & & $0.50^{\mathrm{a}}$ & $0.50^{\mathrm{a}}$ \\
\hline Ash & $25.10 \pm$ & $25.00 \pm$ & $22.23 \pm$ & $20.00 \pm$ \\
& $0.40^{\mathrm{a}}$ & $0.10^{\mathrm{a}}$ & $0.18^{\mathrm{b}}$ & $1.13^{\mathrm{c}}$ \\
\hline Dry Matter & $89.55 \pm$ & $89.10 \pm$ & $89.86 \pm$ & $89.82 \pm$ \\
& $0.74^{\mathrm{a}}$ & $1.11^{\mathrm{a}}$ & $0.47^{\mathrm{a}}$ & $0.46^{\mathrm{a}}$ \\
\hline Moisture & $10.45 \pm$ & $10.90 \pm$ & $10.14 \pm$ & $10.18 \pm$ \\
Content & $0.74^{\mathrm{a}}$ & $1.11^{\mathrm{a}}$ & $0.47^{\mathrm{a}}$ & $0.46^{\mathrm{a}}$ \\
\hline
\end{tabular}

The above values are means of triplicate data \pm SD.

Mean values in each row with different superscripts are significantly different $(\mathrm{P}<0.05)$.

Key:

CA FM = Clarias Group A fishmeal
CB FM = Clarias Group B fishmeal

CC FM = Clarias Group C fishmeal

CD FM = Clarias Group D fishmeal

\section{Discussion}

This study revealed a direct relationship between fish weight and fillet yield as well as "waste" yield. The bigger the fish, the more the fillet yield and the less the "waste" yields. This conforms to the findings of Souza et al,( 2005) on Oreochromis niloticus and Santos et al,( 2000) on Hoplias malabaricus. A range of $31.85 \%$ to $39.50 \%$ obtained in this study is comparable to $36.80 \%-44.40 \%$ obtained by Bugeon et al., (2010) in rainbow trout and agrees with Oellermann and Hecht (2001) that reported $38.90 \%$ for Clarias gariepinus. The result of $33.00 \%$ for Clarias Group B (500 $\mathrm{g}-999 \mathrm{~g})$ and $35.95 \%$ for Clarias Group C (1.00 kg - 1.499 $\mathrm{kg}$ ) also agree with $34 \%$ reported by Adeyemi et al., (2012) for Clarias gariepinus of body weight ranged between $0.9 \mathrm{~kg}$ and $1.2 \mathrm{~kg}$. However, results of this study differ from that reported by Adeyemo, (2013), who reported

\section{4}

$52.50 \%$ for Clarias gariepinus. Higher fillet yields had also been reported for some other fish species such as $47.43 \%$ 49.79\% for Pirarucu - Arapaima gigas (Forgaca et al., 2011), $56.20 \%-65.40 \%$ for skin-on rainbow trout fillet (Bugeon et al., 2010) and $43.80 \%$ for Clarias gariepinus 5 Heterobranchus longifilis hybrid (Oellermann and Hecht, 2001).

Conversion ratio (raw fish: fishmeal) range of 5.29:1 to 4.48:1 obtained for the production of fishmeal from byproduct of processed Clarias gariepinus in this study agree with 5:1 ratio reported by Akande et al. (2012) as well as with the standard yield obtainable from industrial fishmeal plants (FAO, 1986). Although, the range of $55.87 \%-57$ $.40 \%$ crude proteins obtained from analyzed Clarias fishmeals produced from by-product of processed Clarias 


\section{International Journal of Science and Research (IJSR) \\ ISSN (Online): 2319-7064 \\ Index Copernicus Value (2013): 6.14 | Impact Factor (2015): 6.391}

gariepinus was lower than the range of 59.2\% - 61.9\% crude protein reported by Dale, (2001) for catfish meal, the range of $20.00 \%-25.10 \%$ ash content reported in this work for was similar to the range of $22.8 \%-24.1 \%$ ash content reported by Dale, (2001) for catfishmeal.

\section{Conclusion}

Weight of Clarias gariepinus was found to have direct relationship with its fillet yield. A fish processor is hereby advised to process Clarias gariepinus of weight class $1.5 \mathrm{~kg}-$ $1.99 \mathrm{~kg}$ to get the highest amount of fillet yield. The waste generated from processing Clarias gariepinus of weight class $1.5 \mathrm{~kg}-1.99 \mathrm{~kg}$ is also recommended for fishmeal production since it gave the highest amount of fishmeal yield, crude protein content and lowest ash content of the fishmeal produced thereby making it most desirable for compounding diets for growing fish and other livestock.

\section{Acknowledgements}

To Department of Fish Technology, Nigerian Institute for Oceanography and Marine Research (NIOMR), Lagos, Nigeria for the provision of laboratory with processing equipment.

\section{References}

[1] Adeyemi, R. S., G. R. Akande, A. Oresegun and O. A. Ayinla 2012. Small Scale Processing of Farmed catfish (Clarias gariepinus): Fillet yield and proximate composition. In proceedings of $36^{\text {th }}$ Annual Conference Nigerian Institute of Food Science and technology, Lagos. Pp 435 - 437.

[2] Adeyemo, A. O., 2013. Estimation of fillet yield for four tropical freshwater fish species. Merit Research Journal of Environmental Science and Toxicology Vol. 1 (2) pp 012-015.

[3] Akande, G.R., A. Oresegun, A.O. Osibona, Edah Bernard and Ayo-Olalusi C.I., 2014. Utilization of stunted Tilapia as replacement for imported fishmeal in the diet of Clarias gariepinus fingerlings. American Journal of Food Science and Nutrition. Vol. 1, No. 3, pp 33-42.

[4] Akande, G. R, R. S. Adeyemi, A. O. Olusola and A. Oresegun 2012. Fabrication and Testing of a prototype cottage level fish meal plant. In proceedings of $36^{\text {th }}$ Annual Conference, Nigerian Institute of Food Science and technology, Lagos. Pp 262-263.

[5] Alceste, C. C. and D. E. Jory 2000. TILAPIA Alternative protein sources in Tilapia Feed Formulation. Aquaculture Magazine Jul/Aug. 2000 Volume 26(4):3.

[6] A. O. A. C. (Association of Official Analytical Chemist) 2000. Official Method of Analysis $17^{\text {th }}$ edition. A. O. A. C. International, Gaithersburg, Maryland.

[7] Bugeon J., F. Lefevre, M. Cardinal, A. Uyanik, A. Davenel and P. Haffray 2010.Flesh quality in large rainbow trout with high or low fillet yield. Journal of Muscle Foods vol. 21, issue 4, pp 702-721.

[8] Dale N.M. 2001. Nutrient value of catfish meal. J. Appl. Poult. Res. 10: 252-254.

[9] Fagbenro, O. A. and I. A. Arowosegbe 1991: Utilization of Agricultural wastes and by-products in fish feeds production in Nigeria. Proceedings of $6^{\text {th }}$ Annual FISON Conference, Lagos: $121-130$.

[10] Fagbenro, O. A., E. O. Adeparusi and W. A. Jimoh 2013. Haemotological Profile of Blood of African catfish (Clarias gariepinus, Burchell, 1822) fed sun flower and sesame meal based Diets J. Fisheries and Aquatic Science 8 (1): 80 - 86.

[11]Fogaca, F. H. dos Santos, E. G. de Oliveira, S. E. Q. Carvalho and F. J. de Seixas Santos 2011. Yield and composition of Pirarucu fillet in different weight classes. Acta Scientiarum Animal Sciences. Maringa, v. 33, n. 1, p.95- 99.

[12] Faturoti E. O., 2000. Beneath the ripples and sustainable fish production. Inaugural Lecture, University of Ibadan. 54 Pp.

[13]FAO (Food and Agriculture Organization). 1986: The Production of Fishmeal and oil, FAO Fish Tech. Pap., (142) Rev. 1:63p.

[14]FAO (Food and Agriculture Organization). 1998: The State of World Fisheries and Aquaculture. FAO Fisheries Department, Rome, Italy: 112.

[15]Garibaldi, L., 1996 List of animal species used in aquaculture. FAO fisheries circular No. 914.

[16] Idodo-Umeh, G. 2003. Fisheries Fishes of Nigeria (Taxonomy, Ecological Notes, Diets and Utilization). Idodo-Umeh Publishers Ltd. Benin City. Pp 232.

[17] Oellermann L. K. and T. Hecht 2001. Comparison of fillet yield, protein content and amino acid profile of Clarias gariepinus and the Clarias gariepinus 5 Heterobranchus longifilis hybrid. Aquaculture Research: 31 (7): 553-556.

[18]Rival, B. 2011: Learn How to Fillet A Fish. FineFishing .com 5

[19] Santos, B.A., Melo, J.F.B., Lopes, P.R.S. \& Malgarim, M.B. (2000). Composicao quimica e rendimento Do file da traira (Hoplias malabaricus). Revista da Faculdade de Zootecnia, Veterinaria e Agronomia, v.7-8, n.1, p. 3339.

[20] Souza, M. L. R., E. M. M. Vegas. P. J. A. Sobral and S. N. Kronka 2005. Efeito do Peso de Tilapia do nilo (Oreochromis niloticus) sobre o rendimento e a qualidade de seus files defumados com e sem pele. Cienc. Tecnol. Aliment; Campinas, 25(1): 51-59. 